\title{
Impacts of the online Gambling Prohibition Policy - A Comparative Survey of Brazil versus the European Union
}

\author{
Impactos da Política da Proibição do Jogo on-line - Uma Pesquisa \\ Comparativa Brasil versus União Europeia
}

\author{
João Ricardo Catarino ${ }^{1}$ \\ José Duarte Cordeiro ${ }^{2,1}$ \\ Ricardo de Moraes e Soares ${ }^{1}$ \\ ${ }^{1}$ Universidade de Lisboa, Portugal \\ ${ }^{2}$ Ministério das Finanças, Portugal
}

\begin{abstract}
Online gambling is a form of gambling. Its direct ban or lack of regulation leads to loss of revenue. These are used to support the social functions of the state. In this research we analyse the estimates about the relevance of online gambling, taking as a reference the European Union where online gambling activity is allowed. These data are compared with estimates for Brazil that does not allow online gambling. Some principles on game regulation are proposed, which can serve the Brazilian case, based on the experience of European and world regulation.
\end{abstract}

Keywords: Online Gambling. Taxation. Social Purposes. Regulation.
Resumo: O jogo on-line é uma modalidade dos jogos de fortuna ou azar. A sua proibição direta ou por falta de regulamentação induz perda de receitas, que são usadas para apoiar as funções sociais do Estado. Nesta pesquisa, foram analisadas as estimativas sobre a relevância do jogo on-line, tomando-se como referência a União Europeia, já que lá a atividade de jogo on-line é permitida. Esses dados foram comparados com as estimativas para o Brasil, país que não permite o jogo on-line. Propõem-se alguns princípios sobre a regulamentação do jogo que podem servir para o caso brasileiro, tomando-se por base a experiência da regulamentação europeia e mundial.

Palavras-chave: Jogo on-line. Tributação. Fins Sociais. Regulamentação.

Recebido em: $12 / 08 / 2020$

Revisado em: 24/08/2020

Aprovado em: 26/08/2020 


\section{Introduction}

Gambling is a historical and social phenomenon considered to be a pernicious and unwanted activity. It began to be the target of absolute prohibition which practice was repressed and condemned. However, the increase in illegal gambling and its wide influence in social problems led to regulation as a way to protect society and individuals.

The legal prohibition of random gambling had mainly moral concerns and it was its vicious, if not immoral, character that was sought to be achieved. The need to safeguard heritage, security, peace and public order was invoked, avoiding feuds, schemes, fraud and other crimes.

Clímaco (2006, p. 482) points out that "[...] despite the liberalization $[\ldots]$, the conservative element that always involved the game for various reasons - cultural, political and above all moral [...]" still remains. Duarte $(2001$, p. 89$)$ states that "[...] the values protected by the rules, particularly of a criminal nature, are good customs, property and the tax interest". However, it is undeniable that there are negative aspects related to the practice of gambling that have important repercussions on societies, causing damage not only to themselves, but also to third parties, which can affect fundamental legal assets.

The regulation of the sector is decisive for channeling demand towards the legal supply side and adapting this supply to the markets size. It allows to control harmful aspects related to the illicit practice of games of chance, such as fraud, money laundering, corruption, tampering sports results, access by minors and compulsive gamblers and misleading advertising. However, technology emerges with all its virtues and online gambling needs that sovereign states take restrictive measures and regulate differentially these services effectively as considering sector specificities, such as the lack of direct contact, between the user and the operator, and the easy access to online games in an isolated environment, with no social control.

For more than a decade, different regimes have been in force in Europe regarding online gambling, ranging from regulated authorization, an absence of legislation to a total ban on gambling, varying between 
different liberalized model degrees. As a rule, States grant licenses to entities that intend to make games available online in their territories subject to compliance with legal requirements and the payment of fees and taxes.

However, the online gaming sector is still a young (but vibrant) segment of the digital economy of our times, being one of the few areas of technology led by European companies. Despite this new paradigm, traditional operators (and monopolies) of land-based games continue to boost their offline revenues while simultaneously expand their online offering.

Thus, the purpose of this empirical research was the online game in Brazil. The European position was analyzed regarding the reality of remote gaming, systematizing the sector's evolution through the treatment of statistical elements. The data allowed us to understand the phenomenon of online gambling in all its extent, the evolution trends and the tax revenues level that it provides.

The applicable European law principles are identified and articulated with the European Union Members, which can be applied in the Federated States in Brazil. The evolution of online gaming revenues obtained in Europe and in the World was estimated and Brazil revenue losses were projected. It was observed that social gains resulted from the legalization of online gambling, adopting clear principles and establishing a complete and modern regulatory framework.

We believe that duly regulated online gambling promotes acceptable social behaviors and can be an excellent source of revenue. However, it became evident that areas of collective society were not benefiting from the gambling investments, based on the comparative experience of European game. The research was based on the consultation of bibliography, reports, monographs, legislative sources, statistical data from countries in the European Union and specifically the country under study, Brazil. 


\section{Online Games and Betting - A Global Phenomenon}

At the end of the $20^{\text {th }}$ century, the game's activity was marked by the possibility of being carried out through internet. Traditional forms of gambling (lotteries, bingos, lotos, casino games) are now available in a virtual environment, giving rise to practice of gambling in a new format online gambling ${ }^{1}$.

The virtual space allowed operators to develop their activity without geographical limitations and allowed players to bet remotely, anytime and anywhere. It is known that the human drive for the game is a reality, as a recreational activity that provides fun, pleasure and passion for risk. However, with the enthusiasm and emotion provided by the new gambling and gambling paradigm, a "gray" market has emerged in parallel, where several licensed operators in their countries provide services in other territories without any authorization. With the implosion of fortune games on the internet ${ }^{3}$, those started to compete unfairly with authorized operators, with evident losses of revenue for sovereign states.

Even so, the USA, China, Russia, Pakistan and Brazil prohibit most or all forms of online gambling (WOOD; WILLIAMS, 2009). In Europe, it was Eurobet, based in the United Kingdom, in 1996, who started offering remote gaming. That year Finland granted licenses for online lottery operations to the National Lottery of Finland (VAN DER GASST, 2001). In 1998, many of the biggest online operators were already in

\footnotetext{
${ }^{1}$ Online gambling covers different types of games of chance, such as sports betting, casino games, bingo, poker, horse racing and promotional games, always over the internet, in a virtual environment. In the present research, the mention of «Online Game» refers to games of chance with money bets, over the internet.

${ }^{2}$ For the purposes of this research, the concept of "gray" market is used to describe markets made up of licensed operators in their countries that provide online gambling services in other states, without specific authorization to do so, under the terms of the respective national laws.

${ }^{3}$ Games of fortune or chance are games in which the possibility of winning or losing does not depend on the player's skill, but exclusively on luck. The essence of games of chance is a decision making under risk scenarios, determined by the statistical probability of hitting the chosen combination (result, key, etc.).
} 
activity, such as Party Gaming ${ }^{4}$, which started being listed on the London Stock Exchange in 2005. It is estimated that at the end of 1996 there were around 15 cash gambling sites, more than 200 at the end of 1997, 650 at the end of 1999 and 1,800 at the end of 2002 (SCHWARTZ, 2006). This data indicates that, in 2003, the commercial market for online games in the EU-25 has generated net revenues (total stake, minus the paid prizes) of 51.5 billion euros (EUROPEAN COMMISSION, 2008). According to a study by PWC (2008), that value corresponded to about $5 \%$ of the global gambling market in the EU, and it was estimated that, depending on the region, the online market has grown annually between a minimum rate of $8.4 \%$ and maximum of $17.6 \%$.

In the article «The governments get more addicted to the tax than the players to the games», Eric Pfanner (2010) characterized the regulation of online gambling in several European countries, at a time when US Congress intended to make a 2006 law that banned gambling over the internet more severe, also making transfers from financial institutions to websites of unauthorized online operators illegal. Pfanner (2010) concluded that attempts to ban the practice of online gambling were doomed to failure, arguing that it was better to legalize tax and regulate it.

Today, there are around 4.423 online gambling sites ${ }^{5}$ regulated in activity, configured on virtual platforms with various types of games: poker, sports betting, bingo, casinos, lotteries and skill games, among others. According to the H2 Gambling Capital (H2GC) ${ }^{6}$ consultancy, the USA remains the country with the highest amount spent on online

\footnotetext{
${ }^{4}$ Party Gaming PLC - Created in 1997, proprietary software has evolved to offer innovative solutions in the online gaming market, with exponential growth. Information available at: http://www.ptcasinobonus.com/cassino-software/partygaming.html.

5 Listed at www.online.casinocity.com: directory of information services that acts independently in relation to game operators, updating news about online games available worldwide.

${ }^{6}$ H2 Gambling Capital (H2GC) - General News: international consultant, leader in providing studies on the gaming industry at a global level, very influential for legislators in decision-making on the gambling sector, both in Europe and in the USA. Accessible at: http://www.h2gc.com/news.
} 
games, with around $25 \%$ of the global market share. According to Simon Holliday (2015), founder and director of H2GC: [...]if all states regulated the online gaming sector, it is likely that its growth would reach a $20 \%$ increase next year, with an evolutionary growth potential until $30 \%$, within 10 years. Statistics do not leave much room for questioning the optimism revealed in the sector. Let's look at some results from the global online gambling and betting market. In 2015 the sector registered a net revenue of US\$ 37.91 billion and the forecasts for 2020 point to a value that should reach US\$ 59.79 billion (Graph 1). It should also be noted that the estimated online games market for 2018, in the amount of US\$ 51.96 billion more than doubles compared with the actually verified value in 2011.

Graph 1 - Global Online Gambling Market Value (2009-2020e) (in billions of dollars)

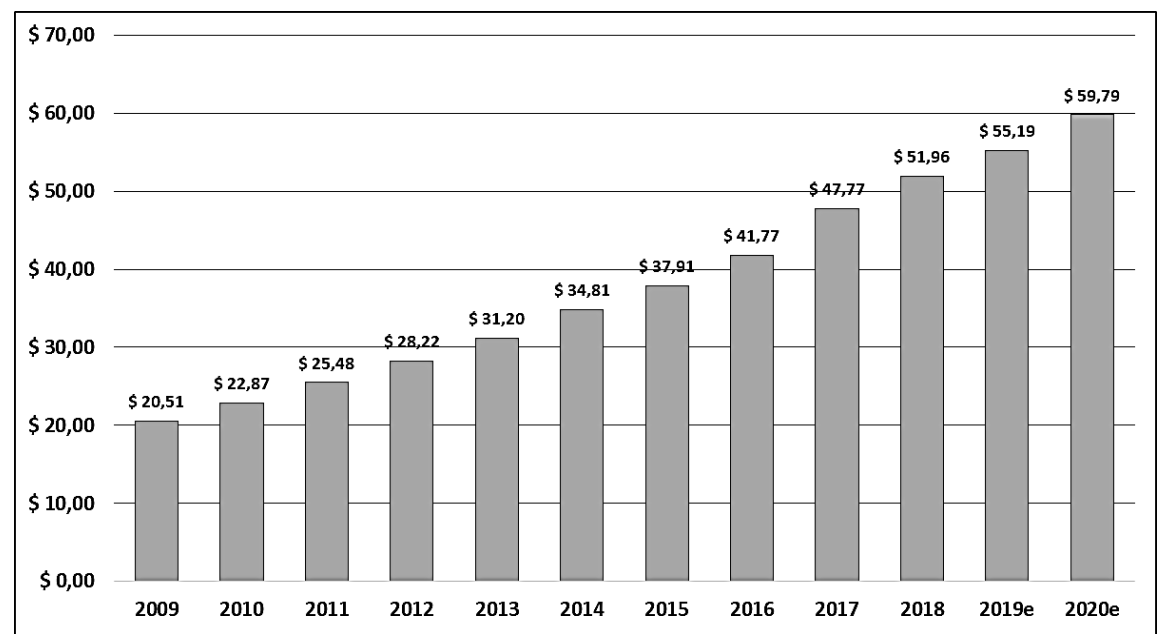

Source: Portal Statista (2019), "Size of the online gambling market"

\section{Brazil: from the casinos in the Imperial Period to the legal void in gambling}

As for games of chance, Brazil assumes one of the most conservative positions in the world, as it does not have regulations that 
allow the practice or exploitation of cash games. In the imperial period ${ }^{7}$, Casinos were meeting places for the Brazilian aristocracy, not only to play roulette, card games and alike, but also to enjoy shows in their luxurious rooms ${ }^{8}$.

It was through a 1946 legal diploma ${ }^{9}$ that Brazil banned the practice of gambling and made it illegal to exploit, with the argument that legal and religious moral tradition of the Brazilian people is opposite to the practice and exploitation of gambling, which were a harmful abuse of morals and good manners.

At the time, there were about 70 casinos concentrated in the southeastern region of Brazil, guaranteeing employment to more than 40000 workers ${ }^{10}$.

In addition to classic ethical, moral or religious discussions, usually of little consequence, games of chance have always existed and will continue to exist, because betting with money based on luck is an inherent cultural aspect of peoples' behavior. In this sense, the French sociologist Loïc Wacquant ${ }^{11}$ advances us: the

7 "Imperial Period" is a period of Brazilian History between September 7, 1822 (Independence of Brazil) and November 15, 1889 (Proclamation of the Republic). During this period, Brazil was ruled by two monarchs: D. Pedro I and D. Pedro II. Information available at http://www.historiadobrasil.net/imperial/.

${ }^{8}$ Luxury room as "Cassino da Urca" ones, in Rio de Janeiro, was the best known casino. Frequented by many celebrities, where the charismatic figure of Carmen Miranda stood out, who performed on stage every week, between 1936 and 1940. Information available at http://www.cassinosdobrasil.com.br/.

${ }^{9}$ Law n. 9215, of April 30, 1946 - Sub-section for Legal Affairs of the Presidency of the Republic of Brazil (Prohibits the practice or exploitation of games of chance throughout the national territory).

${ }^{10}$ General Eurico Gaspar Dutra, until then minister in the government of Getúlio Vargas, was elected President of the Republic of Brazil in January 1946. His objectives were to govern without opposition and to approve his main projects for Brazil, which he achieved. One of the first measures he took was to ban gambling and end casinos.

${ }^{11}$ Loïc Wacquant is a professor of Sociology at the University of California, Berkeley and a researcher at the Center de Sociologie Européenne, Paris. He was a co-founder and editor of the interdisciplinary magazine Ethnography and a regular contributor to Le Monde Diplomatique newspaper. 
[...] practice of gambling is socially accepted and is rooted in the customs of society. The animal game has existed for more than a century (since 1892), having become a misdemeanor in 1941. It is part of the culture and has already become a folklore in our society. Criminal law does not have the power to repeal the economic law of supply and demand. If the demand is not met by the legal market, it will be met by the illegal market.

So, if gambling is a socially tolerated conduct, prohibitive policies tend not to have the desired effects, which is why it appears that almost all countries in the "developed world" have opted for their legalization, through mechanisms of permission, concession or authorization.

The relationship of Brazilians with the internet has changed a lot in recent years, both in terms of the content surveyed and in relation to the various forms of access, namely with the exponential growth of smartphone sales in recent years ${ }^{12}$. However, until now, the 1946 legislation has not been changed and, as such, Brazil maintains its prohibitionist position regarding to the exploitation and practice of gambling.

The rampant growth of the illegal gambling market, due to the lack of regulation in the Brazilian territory, has very harmful consequences, of an economic and financial nature, with the withdrawal of large amounts of capital without any tax return, despite the gambling taking place on illegal sites.

The loss of revenue for Brazil is evident, as a result of a new offer that expands the range of products available to players, without leaving their physical comfort zones. This compromises public support for social functions that could be supported by gambling revenues.

Online gambling operators in Brazil do so illegally from abroad as the legislation in force has not been revised to fit them. This legislative

12 IDC Brasil (2015), accessible at: http://g1.globo.com/tecnologia/noticia/2015/04/ venda-de-smartphones-sobe-55-no-brasil-em-2014-diz-idc.html. IDC is a leader in market intelligence and consultancy in the information technology, telecommunications and mass consumer technology markets. 
void leaves room for legal interpretations that can motivate wrong behavior by users, beyond the control of the authorities.

However, the 1946 diploma that made betting on physical establishments in Brazil illegal, could not predict the phenomenon of the internet as a non-physical territory. Therefore, Brazilian law does not limit the performance of betting on the web, since internet is not part of the physical territory of Brazil.

Thus, Brazilians can bet on the gaming sites that are available without any illegality, since the servers used by online game operators are being displayed in countries that use this type of activities.

It seems clear that maintaining the current lack of regulation of online gambling, coupled with the transfer of player habits, has a strong impact in tax revenue loss for the State, which could be avoided by legal measures.

At the Brazilian Gambling Congress (RIO DE JANEIRO, 2013) ${ }^{13}$, there was consensus and it was clear that, in 2012, illegal gambling moved almost twice the R $\$ 11.1$ billion (reais) of official games (considering $\mathrm{R} \$$ 10.4 billion from Lotteries of Caixa Económica Federal, $\mathrm{R} \$ 400$ million from State Lotteries and R\$ 300 million from Turfe ${ }^{14}$ ) without any counterpart of these resources to the State or to society.

${ }^{13}$ The Brazilian Gambling Congress took place in Rio de Janeiro between 18 and 20 November 2013, with the participation of 250 delegates from all over the world, designed to function as a high-level platform for exchanges between players in the gambling markets (online and offline). Accessible at: http://www.brasiliangamingcongress.com/.

${ }^{14}$ Turf is the name of the sport that promotes and encourages horse racing. The promotion of horse racing and the sale of bets on Brazilian territory is governed by federal law (Law 7291 of 19 December 1984 - Law of Turf). 
Graph 2 - Amount collected by Caixa Lotteries (2011 to 2016) (in billions of reais)

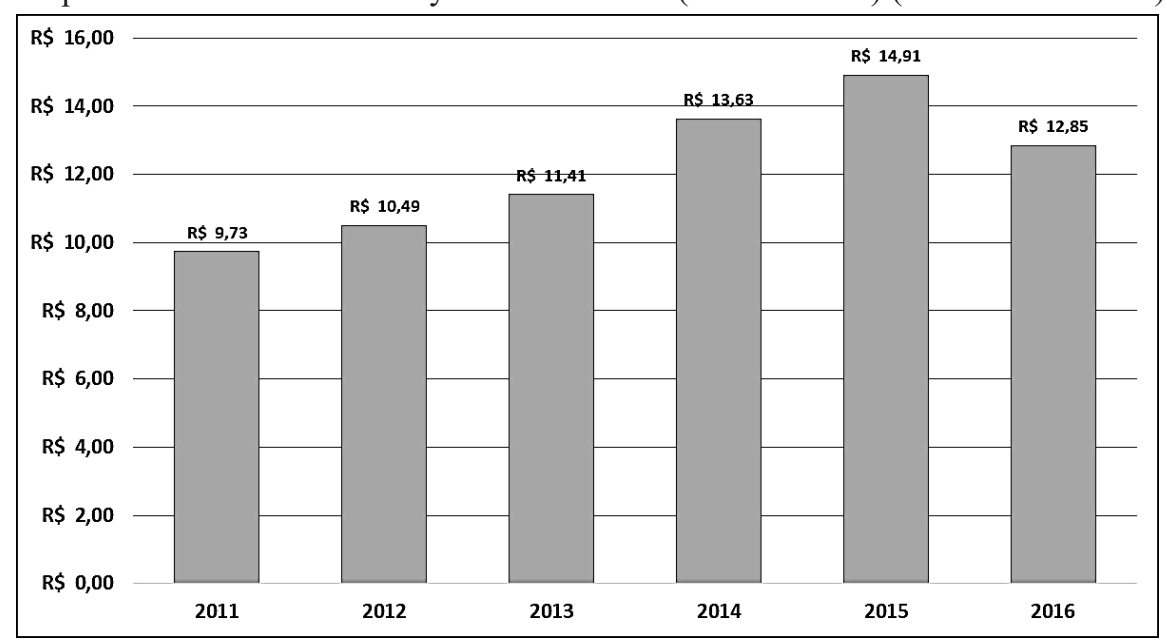

Source: SUALO - National Lottery Superintendence ${ }^{15}$

Caixa Económica Federal does not recognize any type of lotteries or sweepstakes sold over the internet, except for the Internet Banking Caixa (IBC) channel, where bettors can enjoy the convenience of placing their bets over the internet, but only in authorized regular contests. Caixa also does not authorize the use of links or brand citations to any of its products.

As president of the Brazilian Legal Game Institute (IJL) and founding member of the Lottery News Bulletin (BNL), Magnho José argues that "the question of games should be discussed, as clandestinity does not cancel the practice; in the case of gambling we only have two options: legal or illegal gambling; the "no game" option is impossible, as more than 20 million Brazilians play every day in the "most brazillian" animal game, not to mention other modalities".

\footnotetext{
${ }^{15}$ Accessible at: http://www.caixa.gov.br/Downloads/caixaloterias/LOTERIAS_valores arrecadados_2016.pdf.
} 


\section{The First Push for Legalization of Gambling in Brazil}

The money wagered on online games is still a profit for operators, mostly external, who are not subject to any public tutelage in Brazil, creating a lack of security and protection for players and direct loss of tax revenue.

The legalization of online gambling in Brazil would have, as a natural consequence, the increase in public revenues, the reinforcement of public investment in social areas where millions of Brazilians claim for improvements, in regional development through tourism and in the financing of the practice of sports, discouraging clandestine bets at the same time.

The most recent IPSOS ${ }^{16}$ studies conclude that around 8.7 million people regularly play some type of online game in Brazil of which 2 million play online poker. Even though illegal in Brazil, online betting companies profit from customers more than US\$ 200 million (dollars) annually.

Some data presented by IPSOS deserve to be highlighted: (i) among the 193 member countries of the United Nations (UN), 76\% have legalized and regulated gambling, where Brazil is among the other 24\%; (ii) among the 156 countries that belong to the World Tourism Organization, 71\% have legalized and regulated gambling; of the 34 countries that constitute the Organization for Economic Cooperation and Development (OECD), a group of rich or developed countries, only Iceland does not allow the practice of games in its territory; (iii) finally, in the framework of the G20 (where Brazil belongs), 93\% of its members have legalized games in their territories, with only 7\% not allowing it: Brazil, Saudi Arabia and Indonesia (where the latter two are Islamic countries).

\footnotetext{
${ }^{16}$ The IPSOS group is part of the global leaders in providing studies and research on marketing, advertising, media, consumer satisfaction and public opinion polls. Founded in France (1975), the IPSOS group is independent, publicly traded and has been traded on the Paris Stock Exchange since 1999. Access at: www.ipsos.com.br.
} 
Adding data from Global Betting and Gaming Consultants ${ }^{17}$ (2014) where Brazil is the 23rd country that most bets through internet (published in the "Folha de São Paulo" newspaper, 05/05/2014).

The consultant also adds that the contribution of Brazilians to the global online market, with bets on sites located outside its country, reveals their eagerness for online sports betting (mainly in football games) and leaves clear indications of the revenue losses that could come from taxation.

According to "Viver Brasil" magazine (07/03/2015), the return of the casinos would encourage tourism, employment, income and would, to a large extent, prevent the relocation of Brazilian players to countries such as the United States, China, Portugal, Argentina, Peru or Uruguay. Indeed, it is concluded that Brazil is among the countries with the biggest loses derived from banning gambling in all its aspects (Revista Época Negócios magazine, 02/09/2015).

The data suggests that legalizing all gambling by electronic means is the most intelligent and sensible way to deal with the phenomenon since the legal void generates a great loss of revenue for the interests of States, with significant socio-economic impact. However, legislating online games of chance in Brazil would require a consideration of their consequences, given the complexity of the topic and the multiplicity of disciplines that implies, from taxation issues, revenue sharing among the Federative Entities to criminal matters and sanctioning.

In this regard, reference is made to a legal principle consensually signed and clarified by Bueno (1998, p. 437): “[...] The application of the principle of responsibility will lead the courts to sanction civil or criminal penalties for service providers, or internet servers, that have no security measures, considering the advancement of technology".

\footnotetext{
${ }^{17}$ Global Betting and Gaming Consultants (GBGC): data repository, studies and reports for the global gaming industry market. It provides consultancy and advice based on its experience, with more than 50 years operating in different areas of the sector of games of chance.
} 
On December 9, 2015, the Special Commission for National Development (CEDN), under the supervision of the Federal Senate of Brazil, approved Senate Bill n. 186/2014, which proposed to regulate the exploitation of games of chance throughout Brazilian territory (BNL, $2015)^{18}$.

The article became part of the so-called Brazil Agenda ${ }^{19}$ with the aim of encouraging and boosting the resumption of the country's economic growth. Accordingly, the proposals contained in the diploma, aimed at the operation of casinos and bingo halls in Brazilian territory, gambling legalization and measures to regulate online gambling and betting.

The project, by Ciro Nogueira ${ }^{20}$, included the definition of the types of games that can be explored, the criteria for granting licenses and the rules related to the payment of prizes and collection of taxes. According to Ciro Nogueira, "the prohibitive legislation did not change the scenario of illegal gambling in Brazil, which moves more than R\$ 18 billion (reais) in illegal gambling annually with gambling, bingo, sports betting and internet poker".

The senator states that

Brazil isn't collecting around R\$ 15 billion (reais) annually due to the lack of regulation of gambling", and adds, "in addition to generating jobs and greater circulation of wealth, decriminalization of gambling will result in an increase of public revenues due to taxation on the activity and, furthermore, it can strengthen regional

\footnotetext{
${ }^{18}$ The BNL (Newsletter Lotteries News) is a daily newsletter with news about lotteries, bingos, casinos, turf, slot machines, bets and animal games. BNL also monitors bills in progress in the National Congress, judicial decisions and official acts of government lotteries.

${ }^{19}$ The Brazil Agenda was implemented in 2015 with a view to resuming economic growth through reforms to overcome the economic crisis. The measures proposed by Agenda Brasil can be consulted on the Senate website.

${ }^{20}$ Ciro Nogueira Lima Filho is a Brazilian lawyer, businessman and politician. He currently serves his second term as senator for Piauí and the national presidency of the Partido Progressista.
} 
development policy through tourism. It is the type of project in which the government wins and society wins too.

In justifying PLS 186/2014 (p. 12), Senator Ciro Nogueira cites the "Study of the Illegal Gambling Market in Brazil"", where it is estimated that Brazilians bet around US\$ 800 million (dollars) annually through the global online networks, in bingo, casino games, sports betting and poker modalities.

These proposals do not revert any financial counterparts to Brazil, which would be really needed for sectors development in the country. As such, it is imperative that all parties involved discuss and move towards the legalization of online games, so that they are removed from the sphere of illegal operators who do not pay taxes and who, therefore, do not contribute to society.

\section{The Gaming Industry in the European Union}

The European Union (EU) does not intend to harmonize gambling regulations and does not establish specific rules in terms of establishment autonomy and free access to markets by gambling operators. Therefore, it is up to each Member State to outline its regime for online gambling, respecting the fundamental principles, law and jurisprudence of the EU institutions.

However, with regard to consumer protection, the European Commission warns Member States of four fundamental aspects that must always be taken into account:

(i) Games advertised as "free" must not mislead the consumer about the costs actually involved;

\footnotetext{
21 "Study of the Illegal Gambling Market in Brazil", presented in 2012, at the International Seminar held in Mar Del Plata, Argentina, promoted by the "Instituto de Lotería y Casinos de Buenos Aires" and "Asociación de Loterías y Argentina Casinos-ALEA". Access at: http://www.bnldata.com.br/blogPost.aspx?cod=17952.
} 
(ii) Playful games must not induce minors to acquire certain elements without the consent of their parents;

(iii) Consumers should be informed about payment methods and purchases should not be charged without their knowledge;

(iv) Operators must provide an email address for consumers who wish to clarify doubts or complain.

From EU perspective, the North American model of banning gambling is in opposition to to the World Trade Organization (WTO) rules. EU defends the controlled regulation model. However, there are no common, legal and regulatory rules for online gambling in the EU. ${ }^{22}$

The creation of these rules (including tax) is a responsibility of the Member States and the monitoring of the compatibility of national rules with European rules is a responsibility of the Commission and the Court of Justice of the European Union (CJEU) ${ }^{23}$. The latter has understood that the Member States' restrictions on gambling activities are not contrary to European law, as long as they aim at protecting consumers, preventing fraud and crimes, in short, ensuring public order. Although online gambling in Europe can be seen as a successful sector of activity, it should be borne in mind that it is a relatively young market, with development processes that are slowing down as regulatory pressure grows.

Net revenue from online gambling is expected to increase from $€$ 16.5 billion in 2015 to $€ 24.9$ billion in 2020 . In 2015 , the online gaming sector in Europe represented $17.5 \%$ of the total market value (online and offline). The forecasts for sector evolution anticipate an increase, continuous and sustained, of $22 \%$ in 2020 . However, the revenue of the

${ }^{22}$ The relative failure of the attempt to introduce a liberal gambling model in the United Kingdom in 2001 was not unconnected, since it did not require obtaining a prior license and paying taxes in its territory, allowing online operators located in tax havens would continue to serve British players.

${ }^{23}$ Some cases submitted to the CJEU: SCHINDLER (proc. C-275/92), LAÄRA (proc. C-124/97), ZENATTI (proc. C-67/98), ANOMAR (proc. C-6/01 ), GAMBELLI (proc. C-243/01), LINDMAN (proc. C-42/02) MARKUS STOSS (C-359 and 360/07 and 409 and 410/07), CARMEN MEDIA GROUP (C-46/08 ), ENGELMANN (C-64/08), SOCIÉTÉ ZETURF (C-212/08) and SJÖBERG (C-447/08 and C-448/08)]. 
market for land-based games (offline) will also increase from $€ 77.7$ billion in 2015 to $€ 84.3$ billion in 2020 , so the growth of the online market will not be achieved to the detriment of the traditional gambling market.

There are several reasons to expect continued growth in the online gaming market. From the outset, the increase in the use of smartphones and other mobile devices, technology, the growing use of the internet, changing consumer habits, as well as the gradual consolidation of regulations in several European states.

In the following graph, we can see the consistency in the growth of online gambling in Europe, including its evolution until the end of 2018.

Graph 3 - Value of the online gambling market in Europe (2009-2018) (in billions of euros)

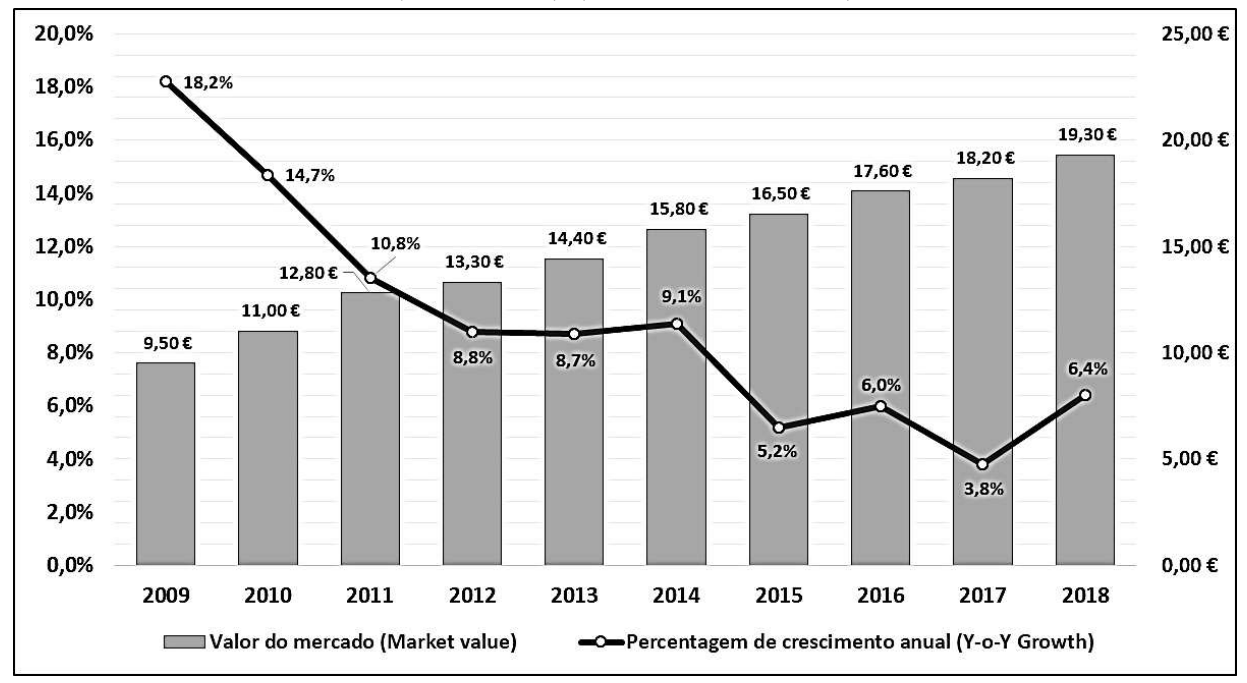

Source: H2 Gambling Capital and iGaming Business Magazine

Regarding regulatory models, trend has been to adopt the so-called liberal regimes, models receptive to private operators and open to foreign investment. 
In fact, the regulation of online gambling in the EU is characterized by the diversity of legal frameworks, with few States prohibiting gambling on the internet. However, in some cases, monopoly regimes (with online gambling and betting) remain, usually protected and managed by the State, either through a public operator or through a private operator with exclusive concession.

However, what happens is a progressive implementation of legal regimes for online gambling and there are even more jurisdictions with licensing systems. Although there is a huge diversity of legislative solutions for the regulation of online gambling, the current scenario suggests that the local license regime (local licensing market) based on the existence of licensed operators that provide services within a strictly regulated framework at national level, is prevailing. The alternative would be a monopoly regime of strict control by the State. This proactive European attitude towards online gambling has allowed European States not only to regulate the phenomenon controlling it better, but also to obtain essential revenues for the rebalancing of their public accounts (CATARINO, 2013). 
Frame 1 - General rules of the models adopted in Brazil (proposal) and in the European Union

\begin{tabular}{|c|c|}
\hline & \\
\hline $\begin{array}{l}\text { - This proposal allows the exploitation of the } \\
\text { "animal game", electronic games (video- } \\
\text { lottery and video-bingo), casino games in } \\
\text { resorts and online games; } \\
\text { - Exploration depends on a prior license } \\
\text { by an agency to be defined by the federal } \\
\text { government and authorization by the States } \\
\text { and the Federal District; } \\
\text { - In order to be authorized for exploration, } \\
\text { the company must demonstrate "technical } \\
\text { capacity", "fiscal compliance" and "financial } \\
\text { standing"; } \\
\text { - Anyone who exploits gambling without } \\
\text { authorization, is subject to imprisonment from } \\
\text { three months to one year and a penalty; } \\
\text { - The penalty is also applied to companies that } \\
\text { allow children under } 18 \text { to enter places where } \\
\text { games are played; } \\
\text { - Anyone who defrauds, seeks to control game } \\
\text { results or pay prizes in breach of the law, is } \\
\text { subject to imprisonment from six months to } \\
\text { two years and a fine. }\end{array}$ & $\begin{array}{l}\text { - Basic requirements must ensure that } \\
\text { consumers have sufficient information about } \\
\text { the risks associated with gambling; } \\
\text { - Commercial communication - advertising and } \\
\text { sponsorship - must be carried out responsibly; } \\
\text { Member States must ensure that minors do not } \\
\text { have access to gambling, in accordance with } \\
\text { rules that are in place to minimize their contact } \\
\text { with gambling; } \\
\text { - There must be a registration process for } \\
\text { individual accounts, which will allow operators } \\
\text { to keep records of players' behavior and trigger } \\
\text { the necessary alerts; } \\
\text { - Players must have access to support services } \\
\text { to ask for assistance regarding their relationship } \\
\text { with the game, and must be able to exclude } \\
\text { themselves from gambling websites; } \\
\text { - Member States should ensure that training } \\
\text { is provided for online gambling operators to } \\
\text { ensure a good understanding of the problems } \\
\text { linked to the phenomenon and to acquire skills } \\
\text { for an appropriate relationship with players. }\end{array}$ \\
\hline
\end{tabular}

Source: Prepared by the authors of this article 
Frame 2 - Frameworks and taxation regimes in some European countries

\begin{tabular}{|c|c|c|}
\hline Countries & Regulatory Framework & Tax regime \\
\hline Cyprus & $\begin{array}{l}\text { The practice of gambling and betting } \\
\text { is regulated through local, specific and } \\
\text { autonomous licensing, and only online } \\
\text { betting is authorized and can be carried } \\
\text { out on sporting and non-sporting events. } \\
\text { Since the approval of the "Betting Law } \\
\text { of 2012" (The Beting Law of 2012) } \\
\text { licenses for interactive betting have been } \\
\text { allocated where the charge depends on its } \\
\text { duration and, in addition, a bank guarantee } \\
\text { deposited in a financial entity based in } \\
\text { Cyprus or in another European Union } \\
\text { country. }\end{array}$ & $\begin{array}{l}\text { Under the licensing regime in force, } \\
\text { online betting operators are subject to } \\
\text { an effective tax of } 13 \% \text { on net revenues: } \\
10 \% \text { in favor of the central government, } \\
2 \% \text { for the Cypriot senior sports } \\
\text { authority (Cyprus Sport Organization) } \\
\text { and a additional } 1 \% \text { to finance } \\
\text { responsible gambling initiatives by the } \\
\text { regulatory authority. }\end{array}$ \\
\hline Spain & $\begin{array}{l}\text { The exploitation of games of chance } \\
\text { in Spain is subject to authorization by } \\
\text { the supervisory body with competences } \\
\text { assigned for its regulation: if the scope } \\
\text { of marketing is national, the competent } \\
\text { regulator is the Directorate-General } \\
\text { for the Ordering of the game (DGOJ). } \\
\text { If the scope is that of an Autonomous } \\
\text { Community, competence is assigned to the } \\
\text { corresponding autonomous administrative } \\
\text { unit. Thus, online games with national } \\
\text { coverage, contests and lotteries are a state } \\
\text { competence. In the sphere of autonomous } \\
\text { competences there are games in casinos, } \\
\text { bingos, lotteries of an autonomous scope } \\
\text { and other games of a traditional character. }\end{array}$ & $\begin{array}{l}\text { The tax regime in force for online } \\
\text { gambling and betting is provided for } \\
\text { in "Ley 13/2011, de } 27 \text { de mayo, de } \\
\text { Regulacion del Juego" (the Law of the } \\
\text { Game) which regulates, in particular, } \\
\text { the activity of gambling and betting } \\
\text { at money when developed through } \\
\text { electronic, computerized, telematic } \\
\text { and interactive channels. Since its } \\
\text { entry into force, the Gambling Law } \\
\text { has provided for taxation in two } \\
\text { areas: a tax on all online (state) } \\
\text { gambling activities and a fee for the } \\
\text { administrative management of those } \\
\text { games. The tax rate differs according } \\
\text { to the type of game, the lowest being } \\
10 \% \text { (random combinations) and the } \\
\text { highest } 25 \% \text { (all other games). More } \\
\text { recently, through Law } 6 / 2018 \text {, of July } \\
3 \text {, the Spanish government introduced } \\
\text { relevant news in the gambling taxation } \\
\text { system, significantly reducing the tax } \\
\text { on all online gambling and betting, with } \\
\text { tax rates of } 25 \% \text { to } 20 \% \text {, and setting } \\
\text { all taxable bases on the operators' real } \\
\text { profit. }\end{array}$ \\
\hline
\end{tabular}




\begin{tabular}{|c|c|c|}
\hline Countries & Regulatory Framework & Tax regime \\
\hline Malta & $\begin{array}{l}\text { The first legislation on online gambling and } \\
\text { betting in Malta was enacted in } 2000 \text { (Public } \\
\text { Ordinance Lotto L.N. 34, 2000). In April } \\
\text { 2004, after the reform and reevaluation of } \\
\text { the initial legislation, the Remote Gaming } \\
\text { Regulation (S.L. 438.04) was published, } \\
\text { becoming the first EU member state to } \\
\text { regulate remote gaming. The Republic of } \\
\text { Malta has, since then, been an established } \\
\text { and reference name in the online gambling } \\
\text { and betting industry, with hundreds of } \\
\text { companies operating from that territory, } \\
\text { benefiting from an attractive tax rate on } \\
\text { income from the exploitation activity (the } \\
\text { lowest in Europe). The market is open to } \\
\text { operators in the European Economic Area } \\
\text { (EEA) and the sector represents around } \\
\text { 10\% of Malta's economy, with the Malta } \\
\text { Authorized Gambling "tag" being an } \\
\text { indication of reliability for those interested. }\end{array}$ & $\begin{array}{l}\text { Online operators, holders of licenses } \\
\text { validated by MGA, pay tax at the rate } \\
\text { of } 5 \% \text { on gross revenue, that is, on the } \\
\text { difference between the stakes and the } \\
\text { payments received, less the amounts } \\
\text { paid in prizes. The scheme was updated } \\
\text { with the approval of the "Gaming Act } \\
2018 \text { " (Chapter } 583 \text { of the Laws of } \\
\text { Malta). }\end{array}$ \\
\hline Portugal & $\begin{array}{l}\text { The regulation of online gambling is } \\
\text { a significant milestone in the history } \\
\text { of gambling in Portugal, marked with } \\
\text { the approval of the Legal Regime for } \\
\text { Online Gambling and Betting (RJO), by } \\
\text { Decree-Law No. 66/2015, of } 29 \text { April, } \\
\text { which placed Portugal alongside the vast } \\
\text { majority of European countries, which, } \\
\text { in the last decade, had already regulated } \\
\text { their exploitation. The complementary } \\
\text { legislation necessary for the } \\
\text { implementation of the defined model was } \\
\text { approved, namely the control, monitoring } \\
\text { and inspection system, managed by the } \\
\text { competent entity - the Games Regulation } \\
\text { and Inspection Service (SRIJ). The first } \\
\text { licenses were granted in 2016, making it } \\
\text { possible to play online with the guarantee } \\
\text { that the game is regulated, supervised and } \\
\text { controlled. Accordingly, the Portuguese } \\
\text { State was able to tax revenues that until } \\
\text { now escaped it, as the amounts spent by } \\
\text { portuguese players and bettors on (legal) } \\
\text { platforms operating in other countries were } \\
\text { not subject to any tax in Portugal. }\end{array}$ & $\begin{array}{l}\text { Online gambling and betting are taxed } \\
\text { through a specific tax - the Special Online } \\
\text { Gambling Tax (IEJO). In terms of subjective } \\
\text { incidence, this tax falls on the exploiting } \\
\text { entities that hold a license, being the objective } \\
\text { tax base defined in the law according to the } \\
\text { category of game or bet and taking into } \\
\text { account the exploration model that underlies } \\
\text { each one. The operating entities are only } \\
\text { taxed in IEJO on income directly resulting } \\
\text { from the exercise of the activity of exploiting } \\
\text { online gambling, with no other tax being } \\
\text { levied on these income. The IEJO's legal } \\
\text { framework for taxation establishes, for } \\
\text { games of chance, a rate between } 15 \% \text { and } \\
30 \% \text {, depending on gross revenue and, for } \\
\text { sports betting, a rate between } 8 \% \text { and } 16 \% \text {, } \\
\text { based on impact on the volume of bets. The } \\
\text { revenue from the tax collected is applied in } \\
\text { accordance with the stipulated in the RJO } \\
\text { and, in particular, is intended to finance } \\
\text { the development of the sports and tourism } \\
\text { sectors. SRIJ itself and the Autonomous } \\
\text { Regions, also benefit from IEJO revenues, as } \\
\text { do other public entities, namely the Service } \\
\text { for Intervention in Additive Behaviors and } \\
\text { Dependencies (SICAD). }\end{array}$ \\
\hline
\end{tabular}




\begin{tabular}{|c|c|c|}
\hline Countries & Regulatory Framework & Tax regime \\
\hline $\begin{array}{c}\text { United } \\
\text { Kingdom }\end{array}$ & $\begin{array}{l}\text { The issuance of licenses for the exploitation } \\
\text { of online gambling was regulated through } \\
\text { the Law on Licensing and Advertising of } \\
\text { Gambling (Gambling Act, 2014) which } \\
\text { came into force on } 1 \text { November 2014, } \\
\text { which determined that remote gambling } \\
\text { operators must have a license from the } \\
\text { regulatory authority to accept players and } \\
\text { to advertise their services in the United } \\
\text { Kingdom, if the equipment or facilities are } \\
\text { located in the territory. The scope of the } \\
\text { subject of the new legal regulation, now } \\
\text { includes all operators that provide online } \\
\text { gambling services to customers physically } \\
\text { located in the United Kingdom, whether } \\
\text { they are resident or non-resident entities in } \\
\text { the territory. }\end{array}$ & $\begin{array}{l}\text { License holders pay tax at a single } \\
\text { (universal) rate of } 15 \% \text { on their profits, } \\
\text { that is, on the difference between the } \\
\text { stakes and payments received, less } \\
\text { the amounts they pay in prizes. The } \\
\text { scheme was implemented through the } \\
2014 \text { Finance Law for remote gaming } \\
\text { (Finance Act, 2014). }\end{array}$ \\
\hline
\end{tabular}

Source: Prepared by the authors of this article

\section{Methodology, Objectives and Results}

The analysis was based on data of turnover and gross revenues of online gambling companies and on tax revenues collected in Portugal, Spain, United Kingdom, Cyprus and Malta for the years 2016, 2017 and 2018. Data from Brazil were estimated from available studies (H2 Gambling Capital and iGaming Business Magazine).

The level of statistical significance for all tests was 5.0\% (0.05). The Shapiro-Wilk tests (Shapiro and Wilk, 1965) were used to determine whether the distribution of variables, for each of the groups, had Gaussian properties. However, due to the absence of Gaussian properties, the application of parametric tests (based on parameters such as means and standard deviations) was invalidated and Mann-Whitney (Mann and Whitney, 1947) and Kruskal-Wallis (Kruskal and Wallis, 1952) were applied. 
The hypotheses put to the test were as follows:

a) H1. The turnover of Brazil's online gambling potential when compared to some European Union countries is statistically significant.

b) H2. The gross revenues from Brazil's online gambling potential when compared to the revenues of some European Union countries is statistically significant.

c) H3. The tax revenues from Brazil's online gambling potential when compared to the revenues of some European Union countries is statistically significant.

Once the turnover, gross and tax revenue values were grouped by country, Gaussian properties (normal distribution of values) for the set of countries under analysis were not confirmed.

Table 1 shows, for each country, the median values of each of the variables under analysis (turnover, gross and tax revenue). Thus, it is possible to state that the values obtained are different, with the median for the United Kingdom being much higher than the other countries, on the other hand, the values obtained for Cyprus are considerably lower. However, it is important to know if these differences are statistically significant.

Table 1 - Median by Country, turnover, gross and tax revenue

\begin{tabular}{cccc} 
& & Median $(\mathbf{m} €)$ & \\
& Volume of business & Gross Revenue & Tax Revenue \\
Brazil (e) & $19.521,4$ & $1.016,4$ & 171,2 \\
Portugal & $1.854,1$ & 122,6 & 54,2 \\
Spain & $13.298,5$ & 559,5 & 139,8 \\
United Kingdom & $115.520,6$ & $5.549,0$ & 832,3 \\
Cyprus & 526,7 & 70,3 & 9,1 \\
Malta & --- & 542,0 & 27,1 \\
\hline
\end{tabular}

Source: Prepared by the authors of this article 
Regarding the Kruskal-Wallis test, which corresponds to the simultaneous comparison of the countries under observation, the null hypothesis is rejected ( $p$-value $=0.000<0.05$ ). This implies that it is not possible to conclude that the revenues from the taxation of online gambling have a significant value in the gross revenues of companies and tax authorities in Brazil. The analysis hypotheses $\mathrm{H} 2$ and $\mathrm{H} 3$, according to which the gross revenues and tax revenues from online gambling are statistically significant, are not valid. On the other hand, the H1 hypothesis in which the turnover of online gambling companies is statistically significant is valid.

Table 2 - Kruskal-Wallis and Mann-Whitney test for turnover, revenue and gross and fiscal (All countries at the same time)

\begin{tabular}{cccc} 
& \multicolumn{3}{c}{ Countries (simultaneous) } \\
& Volume of business (H1) & Gross Revenue (H2) & Tax Revenue (H3) \\
Kruskal-Wallis Test & 3,86 & $-17,42$ & $-9,84$ \\
Degrees of freedom & 2 & 2 & 2 \\
P-valor (bilateral) & 0,07 & 0,000 & 0,00 \\
Mann-Whitney Test & 226275,23 & 11828,97 & 1853,13 \\
P-valor (bilateral) & 0,00 & 0,00 & 0,00 \\
\hline
\end{tabular}

Source: Prepared by the authors of this article

With regard to the statistical comparison between Brazil and some European Union countries, which tax revenues from online gambling, the following results were obtained: hypothesis H1 is valid for the BrazilPortugal, Brazil-Cyprus groups and rejected in the Brazil-Spain and Brazil-United Kingdom and hypotheses 2 and 3 are valid in all groups and rejected in the Brazil-United Kingdom group. 
Table 3 - Kruskal-Wallis and Mann-Whitney test for turnover, gross and tax revenue by country group

\begin{tabular}{|c|c|c|c|c|c|c|c|c|c|}
\hline \multirow[b]{2}{*}{ Grupos } & \multicolumn{3}{|c|}{ Volume of business (H1) } & \multicolumn{3}{|c|}{ Gross Revenue (H2) } & \multicolumn{3}{|c|}{ Tax Revenue (H3) } \\
\hline & $\begin{array}{c}\text { Kruskal- } \\
\text { Wallis } \\
\text { Test }\end{array}$ & $\begin{array}{c}\text { Mann- } \\
\text { Whitney } \\
\text { Test }\end{array}$ & P-valor & $\begin{array}{c}\text { Kruskal- } \\
\text { Wallis } \\
\text { Test }\end{array}$ & $\begin{array}{c}\text { Mann- } \\
\text { Whitney } \\
\text { Test }\end{array}$ & P-valor & $\begin{array}{c}\text { Kruskal } \\
\text { Wallis } \\
\text { Test }\end{array}$ & $\begin{array}{c}\text { - Mann- } \\
\text { Whitney } \\
\text { Test }\end{array}$ & P-valor \\
\hline $\begin{array}{c}\text { Brazil- } \\
\text { Portugal }\end{array}$ & $-11,15$ & 31706,33 & $\mathbf{0 , 0 0}$ & $-22,32$ & 1695,57 & $\mathbf{0 , 0 0}$ & $-12,47$ & 333,88 & $\mathbf{0 , 0 0}$ \\
\hline $\begin{array}{l}\text { Brazil- } \\
\text { Espanha }\end{array}$ & 2,96 & 49661,23 & $\mathbf{0 , 1 1}$ & $-4,15$ & 2355,57 & $\mathbf{0 , 0 0}$ & $-0,67$ & 463,73 & $\mathbf{0 , 0 0}$ \\
\hline $\begin{array}{c}\text { Brazil- } \\
\text { United } \\
\text { Kingdom }\end{array}$ & 33,42 & 202831,48 & $\mathbf{0 , 0 0}$ & 24,27 & 9935,62 & $\mathbf{0 , 0 0}$ & 22,85 & 1518,38 & $\mathbf{0 , 0 0}$ \\
\hline $\begin{array}{l}\text { Brazil- } \\
\text { Cyprus }\end{array}$ & $-16,96$ & 69547,43 & $\mathbf{0 , 0 0}$ & $-26,85$ & 3530,13 & $\mathbf{0 , 0 0}$ & $-29,27$ & 544,76 & $\mathbf{0 , 0 0}$ \\
\hline $\begin{array}{c}\text { Brazil- } \\
\text { Malta }\end{array}$ & --- & -- & -- & $-8,27$ & 4238,88 & $\mathbf{0 , 0 0}$ & $-21,8$ & 572,36 & $\mathbf{0 , 0 0}$ \\
\hline
\end{tabular}

Source: Prepared by the authors of this article

\section{Conclusion}

Social behaviors show that individuals do not stop betting on games of chance just because they are prohibited by law. Bets continue to be placed but in a clandestine manner, with all its associated problems.

Accordingly, the prohibition of betting on games of chance is not the most appropriate way to face the practice (and addiction) of gambling. States must take a proactive role, creating appropriate legislation, other disciplinary rules and implementing consumer protection and enforcement measures, in accordance with the principles in force in their legal systems.

The legalization of online gambling in the EU proves to be advantageous because, in addition to limiting the phenomenon of illegal 
gambling by making a socially relevant activity legal, it has enabled expressive revenue figures, thus supporting important social activities financially. It is estimated that there will be a transformation of the gaming business in Europe with the entry of new operators and the expansion of the offer in a model open to the gaming market, which operates through the allocation of licenses.

By banning gambling, Brazil not only fails to prevent this social transformation of gambling but also puts an activity on the margins, when it deserves institutional attention to protect the different partakers and legalize a relevant social phenomenon. In addition, this marginalization does not prevent the activity of illicit gambling - which is easier nowadays - causes an effective loss of revenue that could very well be used to satisfy important social purposes.

In conclusion, a regulatory model for online gambling activity in Brazil should include, among others, the following aspects:

(i) Only States (in the case of Brazil, the Federated States and the Federal District) are responsible for exploring online gambling and granting licenses to entities that meet the requirements of good repute, technical and economic capacity to be defined by law;

(ii) These, when abroad, must be located in jurisdictions linked to administrative cooperation in the field of taxation, combating fraud and money laundering;

(iii) Regularized contributory and tax status, financial suitability and share capital not less than an amount to be defined;

(iv) Provision of deposits to guarantee compliance with legal obligations and the existence of a subsidiary or branch in Brazilian territory;

(v) Installation of a specific website (site), in the case of Brazil with the domain ".br", for the exploitation of online games and bank account in an institution authorized to exercise activity in that territory; 
(vi) The regime should not, in principle, establish a limit number of licenses which, unless exceptional circumstances, may be renewable for successive periods and be subject to fees to be defined, depending on the type of game;

(vii) Advertising for online gambling, if allowed, should provide limitations to protect minors and the most vulnerable social groups;

(viii) Mechanisms must be created to prevent minors from accessing online gambling, requiring operators to ask for personal data (player name, date of birth, nationality, profession, address, e-mail and general registration number or passport), CPF number, bank account details, namely, IBAN or SWIFT, where payments will be debited and prizes credited;

(ix) The legal possibility of creating a mechanism that confirms the player registers straight away, allowing the operator to verify his age, through public databases, should be considered;

(x) The regime may cover all forms of gambling, in all its modalities, namely: a model for online gambling, open to competition, through licenses but without granting exclusives; a model of territorial exclusives for casinos [assigned to an entity(ies) previously accredited by the Federal Executive Branch, with authorization from the States and the Federal District], with permission to be able to advertise their games and a model legal for the most popular gambling modalities in Brazil - "Bicho" game and Bingo;

(xi) The creation of a new federal physical sports betting game (bookmakers) should be considered, with access available through the "Loteria Caixa" mediator network throughout the country, opening the possibility of betting on the results of official sports competitions.

As a result, in addition to the benefits mentioned, the legalizing games that remain underground and the establishment of clear and objective requirements for operators will contribute to the creation of new jobs, to penalize defaulters, to strengthen the role of the Federal 
Revenue of Brazil (by requiring tax regularity from interested parties) and to encourage regional development policies by increasing tourism and sports activity.

The regime should guarantee integrity and transparency in gambling operations, restricting access to risk groups, ensuring consumer protection and effective control of exploitation, in all its aspects.

The taxation of online operators in Brazilian territory would bring immediate tax revenue advantages and, in addition, by guaranteeing the legal protection of consumers, it would safeguard tax regularity and ensure adequate supervision of the activity. Like many European jurisdictions, with legal regimes that discipline online gambling, and designing an identical model to legalize online gambling in Brazil, the resources obtained could be directed to social, tourism and sport areas, redound the interests of all population. We also identified several positive factors: the protection of minors, the fight against compulsive gambling, the protection of families and property, public safety, in short, providing an environment where social stability must prevail.

It will be up to the National Congress to approve the regulatory initiatives to be proposed by the Government. In addition, Caixa Federal controls (online) in Brasília, more than 34 thousand terminals in 4 thousand municipalities; the Federal Revenue has one of the most competent Income Tax control systems in the world; and the Electoral Court controls 420 thousand electronic ballot boxes with the publication of results in 5 hours.

With the evident advantages that could come from the regulation of gambling in Brazil, there are no consistent arguments that justify its postponement and the maintenance of the current ban that only favors the entities that operate in this legal void. 


\section{References}

AGENCIA ESTATAL DE ADMINISTRACIÓN TRIBUTARIA. Informes anuales de Recaudación Tributaria. 2018. Available in: https://www.agenciatributaria.es/AEAT.internet/Inicio.shtml. Access in: 10 jan. 2019.

AMORIM, Pedro Patrício et al. Leis da Sociedade da Informação: Comércio Eletrónico. Portugal: Coimbra Editora, 2008.

ARJEL - AUTORITÉ DE RÉGULATION DES JEUX EN LIGNE. Bilan comparatif des chiffres d'affaires 2012 des marchés Français, Italien et Espagnol des jeux en ligne. Paris, 2013. Available in: http://www. arjel.fr/IMG/pdf/donnees-supervision-internationales2013.pdf. Access in: 26 nov. 2018.

BALESTRA, Mark; CABOT, Anthony. Internet Gambling Report. St. Charles, MO: River City Group, 2006.

BNL - BOLETIM DE NOVIDADES LOTÉRICAS. Comissão da Agenda Brasil aprova regulamentação dos jogos de azar, 2015. Available in: https://www12.senado.leg.br/noticias/materias/2015/12/09/ comissao-da-agenda-brasil-aprova-regulamentacao-dos-jogos-de-azar. Access in: 26 nov. 2018.

BORCHARDT, Klaus-Dieter. O ABC do Direito da União Europeia. Luxemburgo: Serviço das Publicações da União Europeia, 2011. BUENO, Rocío Ovilla. Internet y Derecho: de la realidad virtual a la realidad jurídica. Boletín Mexicano de Derecho Comparado, [S.l.], n. 92, p. 437-438, 1998.

\section{CASINO CITY, INC. (2013), Online Casino City update sorts}

iGaming operators by currency. Available in: http://online.casinocity. com/article/online-casino-city-update-sorts-igaming-operators-bycurrency-113623. Access in: 14 nov. 2018.

CATARINO, João Ricardo; FONSECA, Jaime. Sustentabilidade financeira e orçamental em contexto de crise global numa Europa de moeda única. Revista Sequência - Estudos Jurídicos e Políticos, Florianópolis, v. 34, n. 67, p. 21-51, 2013. 
CATARINO, João Ricardo; GUIMARÃES, Vasco Branco. Lições de Fiscalidade: Princípios Gerais e Fiscalidade Interna. Coimbra: Almedina, 2015.

CATARINO, João Ricardo; VICTORINO, Nuno. Sociedade de Informação: Coletânea de Legislação. Lisboa: Vislis Editores, 2004.

CESNOVA - CENTRO DE ESTUDOS DE SOCIOLOGIA DA UNIVERSIDADE NOVA DE LISBOA. Inquérito Nacional ao Consumo de Substâncias Psicoativas na População. 2014. Available in: http://www.sicad.pt/BK/EstatisticaInvestigacao/ EstudosConcluidos/Lists/SICAD ESTUDOS/Attachments/135/III InqueritoNacionalConsumo_deSPnaPG\%202012.pdf. Access in: 12 set. 2018.

CLÍMACO, Maria Isabel Namorado. Os jogos de fortuna e azar: o lazer tolerado ou o vício legalizado. In: CLÍMACO, Maria Isabel Namorado. homenagem a José Guilherme Xavier de Basto. Coimbra: Coimbra Editora, 2006. p. 480-484.

CONSELHO DA UNIÃO EUROPEIA. Versões consolidadas dos Tratados da União e sobre o Funcionamento da União Europeia: Carta dos Direitos Fundamentais da União Europeia. 2008. Available in: http://register.consilium.europa.eu/. Access in: 27 fev. 2013.

CORDEIRO, José Duarte. O Novo Regime Jurídico dos Jogos e Apostas Online em Portugal: modelo de regulação e enquadramento global. Revista de Administração Tributária do Centro Interamericano de Administrações Tributárias (CIAT), [S.l.], ed. n. 40, p. 37-56, 2016.

CORDEIRO, José Duarte; NUNES, Vera Vieira. Apostas desportivas online: Regulação e Tributação. Revista OTOC, publicação da Ordem dos Contabilistas Certificados, [S.l.], n. 148, p. 47-63, 2012.

CYPRUS MINISTRY OF FINANCE. Directorate of Administration and Finance. Cyprus Republic. 2016, 2017, 2018. Available in: http://mof. gov.cy/en/. Access in: 8 jan. 2019. 


\section{DGOJ - DIRECCIÓN GENERAL DE ORDENACIÓN DEL JUEGO.} Secretaria de Estado de Hacienda. Available in: https://www. ordenacionjuego.es/es/conocenos. Access in: 10 jan. 2019.

DIONISIO, Pedro et al. Contributos para uma regulação das apostas desportivas online em Portugal. Lisboa: Business School - ISCTE, 2010.

DIRETIVA 2000/31/CE, de 8 de junho de 2000. Relativa a certos aspetos legais dos serviços da sociedade de informação, em especial do comércio eletrónico, no mercado interno (Diretiva sobre comércio eletrónico).

Official Journal L 178/1. Parlamento Europeu e Conselho, 2000.

DIRETIVA 2005/60/CE, de 26 de outubro de 2005. Relativa à prevenção da utilização do sistema financeiro para efeitos de branqueamento de capitais e de financiamento do terrorismo. Official Journal L 309/15. Parlamento Europeu e Conselho, 2005.

DIRETIVA 95/46/CE, 24 de outubro de 1995. Relativa à proteção, tratamento e livre circulação de dados pessoais das pessoas singulares. Official Journal L 281. Parlamento Europeu e Conselho, 1995.

DUARTE, Rui Pinto. O Direito e o jogo. Publicações Themis, [S.l.], v. 2, n. 3, 2001.

EGBA - EUROPEAN ONLINE GAMING \& BETTING ASSOCIATION. Manifesto for a sustainable EU policy for online gambling. 2012. Available in: https://www.latestsportsbonuses. com/sports-news/2012-04-18/update-egba-publishes-manifesto-forsustainable-online-gambling-in-the-eu/. Access in: 15 set. 2018.

FINANCE Act 2014 (chapter 26). Part 3 - General Betting Duty, Pool Betting Duty and Remote Gaming Duty. Royal Assent on 17 July 2014. Available in: http://www.legislation.gov.uk/ukpga/2014/26/contents. Access in: 12 jan. 2019.

GAMBLING COMPLIANCE. Market Barriers - A European Online Gambling Study. 2013. Available in: https:/gamblingcompliance.com/ files/MB3\%20Exec\%20Summary.pdf. Access in: 23 out. 2018. 
H2GC (H2 Gambling Capital). iGaming Business and H2GC in Exclusive Interactive Gambling Data Partnership. 2013. Available in: http://www.h2gc.com. Access in: 4 abr. 2018.

KPMG - INTERNATIONAL COOPERATIVE. Online Gaming: a Gamble or a Sure Bet. 2010. Available in: https://i.forbesimg.com/ forbesinsights/StudyPDFs/KPMG_OnlineGaming.pdf. Access in: 7 jun. 2018.

LEY 13/2011, de 27 de mayo. Regulación del juego (la «Ley del Juego»). BOE, 127, Madrid, Jefatura Del Estado, 28/5/2011.

LOPES, Henrique. Epidemiologia da dependência do jogo a dinheiro em Portugal. Portugal: Centro de Estudos Aplicados da Universidade Católica Portuguesa, 2009.

MATOSO, João. Jogos Sociais: História e Atualidade. Lisboa: Santa Casa da Misericórdia, 2004.

MGA - MALTA GAMING AUTHORITY. The Maltese Land-based and Remote Gaming/ Industry. 2018. Available in: https://www.mga. org.mt/wp-content/uploads/Interim-Performance-Report-2018.pdf. Access in: 16 jan. 2019.

MGA - MALTA GAMING AUTHORITY. Gaming Tax Regulations 2018 - Gaming Act (Cap. 583). Department of Information, 2018. Available in: https://www.mga.org.mt/wp-content/uploads/Gaming-TaxRegulations-2018-1.pdf. Access in:16 jan. 2019.

MORAIS, Luís Silva. O regime do jogo e o direito comunitário. In: SILVA, P. C.; VASCONCELOS, P.; CORDEIRO, A. (coord.). Estudos em Honra do Professor Doutor José de Oliveira Ascensão. Coimbra: [s.n.], 2008. p. 455-512.

MOTA PINTO, Carlos Alberto; PINTO MONTEIRO, António; CALVÃO DA SILVA, João. Jogo e Aposta. Lisboa: Santa Casa da Misericórdia, 1982.

MUNTING, Roger. An Economic and Social History of Gambling in Britain and the USA. Manchester: Manchester University, 1996. 
NBA - NATIONAL BETTING AUTHORITY. Michael Karaoli \& Gregori Afxentiou, 1.439 Nicosia. Call centre: 22601215. Available in: https://nba.gov.cy/en/. Access in: 8 jan. 2019.

OCDE - ORGANIZAÇÃO PARA A COOPERAÇÃO E DESENVOLVIMENTO ECONÓMICO. Implementation of the Ottawa Taxation Framework Conditions. 2003 Available in: http://www.oecd. org/tax/administration/20499630.pdf. Access in: 16 maio 2018.

PALMA, Clotilde Celorico. A Tributação do Jogo em IVA. Cadernos de Ciência e Técnica Fiscal, [S.l.], n. 414, 2004.

PALMA, Clotilde Celorico; SANTOS, António Carlos. A Tributação do Jogo em Portugal: o caso específico da (não) tributação do jogo online. In: PALMA, C. C.; TORRES, H.; FERREIRA, E. (coord.). Estudos de homenagem ao Prof. Doutor Alberto Xavier. Coimbra: Edições Almedina, 2013. p. 147-176.

PORTUGAL. Decreto-Lei n. 66/2015, de 29 de abril de 2015. Termos e condições para o exercício da atividade de exploração e prática dos jogos e apostas online em Portugal. Diário da República, Lisboa, n. 83, I Série, Ministério da Economia, 2015.

PARECER 2013/C 271/09, de 22 de maio de 2013. Parecer sobre a Comunicação da Comissão ao Parlamento Europeu, ao Conselho, ao Comité Económico e Social Europeu e ao Comité das Regiões - Para um enquadramento europeu completo do jogo em linha. Official Journal C 271. Luxemburgo, Comité Económico e Social Europeu. 2013.

PEDIDO de decisão prejudicial 2008/C-55/08, de 13 de fevereiro de 2008. Apresentado pelo Tribunal Judicial da Comarca do Porto (Portugal) - Santa Casa da Misericórdia de Lisboa e Liga Portuguesa de Futebol Profissional versus Baw International Ltd e Betandwin. Com Interactive Entertainment. Official Journal C 92/08. 2008.

PFANNER, Eric. Europe Unleashes Online Gambling to Fill Coffers. The New York Times, New York, 2010. 
PIÇARRA, Nuno. A jurisprudência do Tribunal de Justiça da União Europeia em matéria de jogos de fortuna ou azar: tendências, tensões e paradoxos. Direito \& Desporto, [S.l.], v. VIII, n. 23, 2011.

PIÇARRA, Nuno. Os jogos de fortuna ou azar online perante o direito da União Europeia: o acórdão Santa Casa. In: ARAÚJO, F.; GAMA, J.; OTERO, P. (ed.). Estudos em memória do Prof. Doutor J. L. Saldanha Sanches. Coimbra: Coimbra Editora, Editora, 2011. v. 1. p. 547-579.

PROPOSTA de Resolução A7-0218, de 11 de junho de 2013. Relatório sobre os jogos em linha no mercado interno. Comissão do Mercado Interno e da Proteção dos Consumidores. (PricewaterhouseCoopers International Limited). Global entertainment and media outlook 2013-2017, 2017. Available in: https://www.pwc.com/gx/en/globalentertainment-media-outlook/assets/2013/pwc-global-entertainment-andmedia-outlook-2013-2017-a-guided-tour.pdf. Access in: 17 out. 2018.

REBELO, Paulo. Manual das Apostas Desportivas. Lisboa, Editorial Presença, 2013.

RELATÓRIO 2008/2215 (INI). Sobre a integridade dos jogos de apostas em linha". Comissão do Mercado Interno e da Proteção dos Consumidores. 17 de fevereiro 2009. Available in: http://www.europarl. europa.eu/sides/getDoc.do?pubRef=-//EP//TEXT+REPORT+A6-20090064+0+DOC+XML+V0//PT. Access in: 16 set. 2018.

ROQUE, Vasco Vilares. A Lei do Jogo e seus Regulamentos: Anotada e Comentada. Coimbra: Coimbra Editora, 2011.

SCHWARTZ, David. Roll the Bones: The History of Gambling. New York: Gotham Books, 2013.

SIERRALTA RIOS, Aníbal. Palabras Liminares sobre la Impronta del Comercio Internacional En El Derecho. Boletín Mexicano de Derecho Comparado, [S.l.], p. 1.153-1.158, 2008.

SRIJ - SERVIÇOS DE REGULAÇÃO E INSPEÇÃO DE JOGOS TURISMO DE PORTUGAL. Estatísticas relativas à atividade de Jogo Online em Portugal, 2019. Available in: https://www.srij. turismodeportugal.pt/pt/. Access in: 19 jan. 2019. 
THE BETING LAW of 2012. A Law to Regulate Betting in accordance with Article 52 of the Constitution". Official Gazette of the Republic of Cyprus, [S.l.], n. 106(I). Available in: https://nba.gov.cy/wp-content/ uploads/TheBettingLawof2012.pdf. Access in: 8 jan. 2019.

UK GAMBLING COMMISSION. Annual Report and Accounts 201718. Birmingham: Ordered by the House of Commons to be printed on 12 July 2018, 2018.

UK GAMBLING COMMISSION. Statistics on the regulated gambling industry in Great Britain (GB) for the period April 2015 to March 2018, 2019. Available in: https://www.gamblingcommission.gov.uk/ news-action-and-statistics/Statistics-and-research/Statistics-and-research. aspx. Access in: 12 jan. 2019.

WACQUANT, Loïc. As Duas faces do Gueto. Revista de Políticas Públicas, [S.l.], v. 12, p. 119-120, 2008.

WOOD, Robert; WILLIAMS, Robert. Internet Gambling: Prevalence, Patterns, Problems, and Policy Options. Final Report prepared for the Ontario Problem Gambling Research Centre, Guelph-Canada, 2009. XAVIER, Alberto. Direito Tributário Internacional. Coimbra: Livraria Almedina, 2011.

YÁÑEZ, José; FERNÁNDEZ, Carlos. Anuario del juego en España. [S.l.]: Instituto de Política y Gobernanza de la Universidad Carlos III y Grupo Codere, 2018.

João Ricardo Catarino João Ricardo Catarino is an Integrated Researcher at the Center for Administration and Public Policy (Research Center registered at the Foundation for Science and Technology (FCT)), Institute of Social and Political Sciences, University of Lisbon. PhD in Social Sciences in the specialty of Public Administration at the University of Lisbon. Full Professor of Taxation, Public Finance and Financial Law at the Institute of Social and Political Sciences (ISCSP), University of Lisbon and at the Institute of Accounting and Administration of Lisbon (ISCAL), Polytechnic Institute of Lisbon. Member of several Portuguese 
Tax System Reform Commissions (IVA (1986); IRS, IRC (1989), Property Taxes (2003/2004) and IRS - Personal Income Tax (2014). Judge in arbitration Tax at the Administrative Arbitration Center (CAAD).

E-mail: jcatarino@iscsp.ulisboa.pt

Endereço profissional: Universidade de Lisboa, Instituto Superior de Ciências Sociais e Políticas, Centro de Administração e Políticas Públicas, Polo Universitário, Alto da Ajuda, Rua Almerindo Lessa, 1300-663, Lisboa, Portugal. https://orcid.org/0000-0001-9372-083X

José Duarte Cordeiro is a Tax Inspector in functions in the Studies and Information Department, Fraud Investigation and Special Actions Department, of the Tax and Customs Authority. Master in Taxation and Licensed in Accounting and Administration from Lisbon Institute of Accounting and Administration (ISCAL). Assistant Professor at the Institute of Social and Political Sciences (ISCSP) of the University of Lisbon.

E-mail: jduarte.cordeiro@gmail.com

Endereço profissional: Ministério das Finanças, Autoridade Tributária e Aduaneira, DSIFAE, Avenida Duque d`Ávila, n. 71, 5ª andar, 1000-139 Lisboa, Portugal.

https://orcid.org/0000-0002-4299-482X

Ricardo de Moraes e Soares is an Associate Researcher at the Administration Center and Public Policies (Research center registered at the Foundation for the Science and Technology (FCT)), Higher Institute of Social and Political Sciences, University of Lisbon. PhD student in Public Administration in the specialty of Public Policies. Assistant Professor of Public Accounting, Management and Public Finance at the Institute of Social and Political Sciences (ISCSP), University of Lisbon.

E-mail: rsoares@iscsp.ulisboa.pt

Endereço profissional: Universidade de Lisboa, Instituto Superior de Ciências Sociais e Políticas, Centro de Administração e Políticas Públicas, Polo Universitário, Alto da Ajuda, Rua Almerindo Lessa, 1300-663, Lisboa, Portugal. https://orcid.org/0000-0002-7840-7340 